DANDELION

VOLUME 7 NUMBER I SUMMER 2016
TheODORE KERR is a Canadian born Brooklyn based writer and organizer whose work focuses on HIV/AIDS. He was the programs manager at Visual AIDS and will receive a Masters of Arts from Union Theological Seminary where he researched Christian Ethics and HIV

\title{
Review
}

\section{'AIDS - Based on a True Story'}

Theodore Kerr

A gOlden afternoon in lower Manhattan is Seen a FeW Stories above THE STREET. A thin white woman clings for her life to the side of a skyscraper. A light breeze catches her hair. Traffic moves below. There is no one or nothing to catch her if she falls. ${ }^{1}$

This image, played on loop, is seen early by visitors of 'AIDS - Based on a True Story', an exhibition curated by Vladimir Čajkovac for the German Hygiene Museum. I was in residence at the museum for the exhibition, which closed in February 2016 in Dresden; it will be remounted at the Musée international de la Croix-Rouge in Genève in 2017.

'AIDS - Based on a True Story' is an overall view of the ongoing global pandemic via contemporary art, AIDS posters and historical artifacts. At a cultural moment rich with exploration of early responses to HIV/AIDS, the exhibition upends expectations-and challenges both viewers and institutions to question what an art exhibition can and should do.

Dominating the majority of culture around HIV/AIDS at the current moment-is something I call the AIDS Crisis Revisitation. The first wave begins around 2008, with a revival, of sorts, of AIDS-related media. This is exemplified through the creation and reception of documentary films like Last Address (2010, dir. by Ira Sachs), We Were Here (2011, dir. by Bill Weber and David Weissman), How to Survive a Plague (2012, dir. by David France), United in Anger (2012, dir. by Jim Hubbard); museum exhibitions like 'AIDS in New York: The First 5 Years' (2013, New-York Historical Society) and 'Why We Fight: Remembering AIDS Activism' (2013, New York Public Library); retrospectives on General Idea (2011, Musée d'Art Moderne), Gran Fury (2012, 80WSE, NYU), and Frank Moore (2012, Grey Art Gallery, NYU); gallery shows such as the remount of Rosalind Solomon's 'Portraits in the Time of AIDS, 
1988' (2013, Bruce Silverstein Gallery); books such as Fire in the Belly: The Life and Times of David Wojnarowicz (2013) by Cynthia Carr and The AIDS Generation: Stories of Survival and Resilience (2013) by Perry Halkitis; and the reemergence of AIDS activism through new collectives (such as QUEEROCRACY) and the revitalization of preexisting groups (AIDS ACTION NOW in Toronto, ACT UP in New York and San Francisco).

On screens, on walls, and in discourse, the mass deaths and community responses are remembered through culled and curated video and film footage, photos, and ephemera from personal collections as well as individual and institutional archives. Footage of pre/re-gentrified urban centers populated primarily by passionate white twenty-somethings fighting for their lives conjure up memories and trauma for many who were there, a displaced nostalgia for those who were not, and a desire for many to be able to return to such an engaged moment (without the loss).

The AIDS Crisis Revisitation in its earliest iterations, is both helpful and fraught. In The New Inquiry, Tyrone Palmer wrote about how AIDS history that is 'now remembered and canonized' was appearing 'in memory as decidedly white and middle-class. ${ }^{2}$ Subsequent waves of the Revisitation have widened the view. In 2014 AIDS/art organization Visual AIDS commissioned seven artists to create new works about HIV/AIDS, all falling clearly into the Revisitation with a focus on the past for a contemporary audience. If films like United in Anger and We Were Here can be understood as the first wave of the Revisitation, then the films emerging from the Visual AIDS commission are second wave. What sets them apart is that diverse depictions are a starting point. People of color, people of trans experience, and a mix of the newly living with HIV, long term survivors and those who have long not been with us are woven together within a suite of films rooted in the historical moment of the previous decades of AIDS and now. The first wave was about telling a history that was not being told, the second and third waves then seem to be an exploration of how the past is in conversation with the present and an important coda around how issues including and beyond sexuality impact the AIDS crisis.

It seems important to underline, give the theme of this issue, that I don't think the AIDS Crisis Revisitation is in of itself an exercise in nostalgia, nor would I suggest nostalgia can be understand as being good or bad, productive or not. Rather, nostalgia is complex. Within the Revisitation nostalgia is at play. It stems from the notion of aching for home. For many early responders to the AIDS Crisis, the ACT UP meeting room and other sites of community and activism constitute a home they yearn for years later. It is a well-earned nostalgia, of sorts, for a time of direct action and social change. Later in this essay I will look at a specific work included in the 'AIDS - Based on a True Story' exhibition that explores the impact of what may be considered AIDS nostalgia on those for whom the bulk of their experiences with HIV have come after the introduction of life-saving medication. But for now I will say, responsible work coming out of the Revisitation balances experiences of nostalgia with the reality of pain, and loss.

These various waves of Revisitation come after something I call the Second Silence, a period that begins with the release of life prolonging medication in 1996, and comes to a close with the start of the Revisitation, as well as the 2008 Swiss Statement, a paper issued by the Swiss Federal Commission for HIV/AIDS which stated: 'An HIV-positive individual not suffering from any other STD and adhering to antiretroviral therapy (ART) with a completely suppressed viremia [...] does not transmit HIV sexually, i.e., 
he/she cannot pass on the virus through sexual contact. ${ }^{4}$ In between these two medical advancements was 12 years of silence. At this time there was a drop in the amount of AIDS-related culture - such as books, plays, and activist action - that was being produced and shared. The First Silence of course is the five years between 1981 to 1985 when President Ronald Reagan did not say the word 'AIDS,' which was emblematic of both his administration's failure to properly address the crisis and the systemic homophobia of the time.

\section{Inside the Exhibition}

The Horizon (2013) video scene described above, was created by artist Maja Cule. She did not make it with HIV/AIDS in mind. Rather, she was inspired by a classic film trope: a woman in peril.

But of course, context is everything.

Looking up from the video, the viewer's field of vision is directed upon the canonical 'Silence $=$ Death' image created in 1986 by the political collective of the same name. The Gran Fury poster, Women Don't Get AIDS, They Just Die from It (1991), hung in the next room. This triangulation of art, iconography and urgent messaging exemplified the framework of the exhibition: a commitment to holding the tension of the social, physical and scientific aspects of the ongoing crisis. Čajkovac not only addressed the Hygiene Museum's mission to present exhibitions on 'cultural, social and scientific revolutions taking place in our society, ${ }^{5}$ he created an experience that mirrors the often complex, interconnecting stories and strategies that make up the ongoing AIDS crisis and our various responses.

The Cule video and two AIDS posters provided an entryway to a myriad of questions and conversations about the epidemic. What is the role of the images, symbols and text that are deployed within AIDS activism? How do we reckon with the premature deaths of many HIV-positive women early in the crisis because the Center for Disease Control and Prevention's narrow definition of AIDS meant women were unable to get the care and support they needed? (This is the original impetus of the Gran Fury poster.) In what ways have women impacted the HIV crisis, including as activists who ensured there was a safety net to catch those living with HIV? From these questions, an argument can emerge: the silence around HIV and women is historic and ongoing. It impacts the survival of women living with HIV, and it too easily dismisses the contribution of women in the ongoing response. This is just one conversation amid many that are formed within 'AIDS - Based on a True Story'.

The exhibition was made up of five rooms, each designated by an idea: The Illness of Others, Breaking Silence (in which the video and the posters appear), AIDS As A Media Event, The Virus, and Living Together. In addition, the museum's theatre screened 40 recent AIDS-related public service announcements from 20 different countries, including United Arab Emirates, Germany and South Africa. The exhibition also included a gallery in which 140 of the museum's collection of 10,000 AIDS posters from around the world were arranged by key words such as: war, medicines, syringe, sexuality and contact.

Čajkovac's fascination with classification and key words is a cornerstone of his larger commentary. Science and media-not as disparate as one may think-come together to create, circulate and maintain narratives about illness, wellness and behavior. Čajkovac quotes theorist Paula A. Treichler in the catalogue, 'AIDS is not merely an invented label, provided to us by science and scientific naming practices $[\ldots]$ rather, the very nature of AIDS 
is constructed though language. ${ }^{6}$ This is a large claim, and one that may ring untrue for many. What I think Treichler is saying here, beyond the material reality of the HI virus and the role it plays in relation to an AIDS diagnosis, is that the lived reality of HIV - that is to say, the assemblage that is the social, political, physical, emotional, and spiritual reality of living with HIV - is largely created through text and speech. Laws, gossip, advice, history, disclosure, etc., is how the experience of AIDS becomes known. So while it is important to place the material reality of HIV at the centre of AIDS discourse, it is naive to not take seriously the role language plays in how the material is experienced.

The role of language within the world of AIDS was exemplified by several works in the exhibition; specifically, many works played with the idea of categorizing a virus. One example was a selection of clothes by designer Silvio Vujičić, which were created by a weaving loom he had infected with a computer virus, resulting in modifications in each garment. Another was Forkbomb (2002) by Denis Roio aka Jaromil. Fork bomb is a line of computer code that if entered into a Unix system computer would cause it crash. The code commands the computer to make multiple copies of it, which overwhelms the computer's resources (like HIV overwhelms our body's immune system). Both of these works served as a provocation, begging the question that scientists (and Čajkovac) wrestle with: Is a virus a living thing or a packet of circulating information?

The exhibition also used many popular AIDS narratives to illustrate the ways in which we have incorporated them into our lived experience, and to provide the space to not only understand the function of these narratives but also to question them.

\section{AIDS Famous, AIDS Posters and AIDS Nostalgia}

Throughout 'AIDS - Based on a true Story' a spectrum of the 'AIDS Famous'-a term to denote the specific fame that comes from being associated with HIVpopped up in surprising places. In the AIDS as Media Event room, a video of Elton John singing at Ryan White's funeral played just out of earshot of a poster of activist Linda Carole Jordan and her children. (Jordan was one of the first African-American women to appear on AIDS prevention posters.) Screening in between Elton and Linda was the MTV movie about 'Real World' star Pedro Zamora.

Upon leaving the Media Event room, visitors encountered a large print from Christa Naher's photo collage series Engelordnungen (1991-1994), in which she cut out the familial faces in her personal photographs and replaced them with images of Freddie Mercury. The title of the series means 'Angel arrangements' and the artworks were Naher's way of dealing with HIV in the family.

In many ways, the AIDS Famous become spectres through which we can project, promote and sublimate. It can be easier to deal with celebrities who are living with HIV and those who died from AIDS-related causes, than the HI Virus in the bodies of people we interact with everyday or maybe even our own. In her infamous essay, 'The Uses of the Erotic,' Audre Lorde uses pornography to illustrate what the erotic is not: 'pornography is a direct denial of the power of the erotic, for it represents the suppression of true feeling. Pornography emphasizes sensation without feeling. ${ }^{7}$ In other words, pornography is flat, compared to the unknowable chaotic depth of the erotic. $\mathrm{HIV}$, in all its material and assemblage complexity, is erotic in the sense that it involves and instigates the deepest parts of ourselves and the systems we live in 
for our own survival and the livelihood of others. The AIDS Famous-not the people themselves, but the creation and circulation of their stories-glosses depth in the name of awareness, prevention and other nebulous words that function primarily on the surface of culture. This pornographic experience of AIDS is important and has many roles to play. When dealing with HIV and the tumult of the lived experience, rendering the world flat is a way to avoid any feelings about HIV until there is enough support to dive in. Additionally, if we take Lourde at her word and understand that pornography is not always sexual in nature - rather, the defining feature of pornography is its flatness - then we can see another use of the pornification of AIDS: to make messages about the illness and its impact accessible to the masses.

In our culture one experience of HIV that is frequently rendered flatread: pornographic - is the ubiquitous AIDS poster, a 2D surface often created by committee. The AIDS poster is tasked with the nearly impossible: sharing clear, rational and non-offensive information about a death-causing virus transmitted by sex, drugs and birth. The flatness of the delivery makes nuance and context almost impossible. When it comes to HIV, to borrow from media theorist Marshall McLuhan, the medium of the AIDS poster should not be the message. And yet, it is, and remains, a largely unexamined staple within the AIDS media landscape.

Before he curated 'AIDS - Based on a True Story,' Čajkovac worked at the Hygiene Museum as a research fellow where he embarked on 'an intercultural comparison of posters and their imagery,' a project sponsored by the German Federal Cultural Institution. ${ }^{8}$ In Čajkovac's hands the AIDS posters went from what scholar Lawrence Lessing would call 'Read Only' media files, to 'Read/Write' media files: interactive and instructional cultural objects that communicate beyond their obvious content.

Čajkovac explored the genesis of many of the museum's 10,000 posters-with scientific assistance from Kristina Kramer-Tunçludemir-to find the people involved in creating the work: photographers, illustrators, models and organizers. In the process, many of the posters came alive through personal anecdotes, gossip, cultural context, and sometimes even further mystery about its origin. Čajkovac writes, 'The project began at the point of transition where AIDS posters went from being instruments of health education to museum artifacts, thus transforming the AIDS epidemic into a narrative."9

Extending this idea is the heart of the exhibition, the third room, entitled The Virus. It contains more than a dozen posters from around the world in which HIV is depicted in a variety of ways: as bomb, monster, snake, ocean critter, and yes, even as a virus. The creativity is credited to artists, graphic designers, community members and scientists. As the wall text points out, even the medical community gets creative, colouring microscopic views of HIV to make it more visible. Science is not immune to needing narrative to make an argument.

To animate the lived experience of HIV in The Virus room, Čajkovac curated a series of sculptures from the Hygiene Museum's collection of work from former Red Cross District Manager, politician and artist, Zephania Tshuma (1932-2000). With names such as Checking for AIDS (1988-1992), and AIDS Worm (1988 -1992), Tshuma's sculptures work in an almost inverse fashion to Cule's video of the lone woman on the building. While her video becomes infused with HIV due to proximity, Tshuma's work-made with HIV in mind-delivers an awareness of the factors that surround a community living with HIV: relationships among sexual partners, fear, condoms, folklore and witness. Displayed on a multilayered platform, the works become an uncanny 
reproduction of visitors in the gallery, surrounded by the virus, looking, wondering and indulging in an AIDS related quest for meaning.

\section{AIDS Nostalgia?}

YOUR NOSTALGIA IS KILLING ME reads the text from a 2013 poster that finds a digital rendering of a young teen's bedroom decorated with the 'greatest hits' from the canon of AIDS related art from the late 1980s and early 90s: Gran Fury's Kiss My Lips, General Idea's AIDS Wallpaper, alongside a photo of Justin Beiber in an ACT UP t-shirt, posters of Jonathan Demme's Philadelphia and Derek Jarmen's Blue. This poster was hung near the end of 'AIDS - Based on a True Story' in the room entitled, Living Together, a nod to the globalization of HIV/AIDS but also in the evolving intimacies and tensions around the epidemic.

Created by artist Vincent Chevalier with academic Ian BradleyPerrin-both young men living with HIV - it was commissioned by the Canadian activist group, AIDS Action Now for their poster VIRUS campaign which works with artists to create new work about HIV to paste in urban centers, generating public conversation. The poster trades in images from the past, to make a point about the present. In part it speaks to how alluring the past is especially in the present. Seeing a Gran Fury poster through the foggy lens of history via tumblr has a very different impact than it would have had to come upon it in 1987 in the streets of New York. The same could be true of the lived reality of AIDS itself. Talking to Chevalier and Bradley-Perrin, they tell me the poster was born from their frustration that the cultural past around HIV/AIDS is overshadowing their present and future life chances.

Your Nostalgia Is Killing Me (2013) was met with ire from many senior AIDS activists who saw it as an attack on them and their work. Over 4 days a heated multiple-thread Facebook argument lead Visual AIDS (where I worked at the time) to host a one day event at the New York Public Library about the poster and its impacts. At the event Bradley-Perrin and Chevalier made it clear that it wasn't the history or the retelling of it that was the problem. They draw strength and inspiration from the AIDS activism and culture that came before them and that is still being done. The problem for them is the dislocation of the moments and images being disseminated from the historical and ongoing lived circumstances of HIV/AIDS. In the poster, a laptop open to a tumblr page sits on a bed-a never-ending scroll of decontextualized images. It is this reality that bothers them. The poster makers are not attacking nostalgia per se, and certainly not attempting to police the emotions of early AIDS responders. Rather they are putting into question the serialization of AIDS images within the culture. A good serialization provides context. In their statement they wrote:

It is not the remembering and it is neither the history, nor the material culture nor the valorization of the battles won and lost that impedes our movement forward, but rather the unpinning of our past from the circumstances from which the fights were born. ${ }^{10}$

By quoting the past in their effort to carve out space in the media landscape for their present, Bradley-Perrin and Chevalier are not fighting against nostalgia nor the representation of the past, rather they are fighting for more: more stories, more representation, more times, more interconnectedness. In the face of the dominant position the AIDS Crisis Revisitation has, Bradley-Perrin and Chevalier are throwing open the gates of current AIDS representation to let in 
many stories.

Within the structure of the exhibition, the placement of the poster was powerful. At the late stage that a viewer encountered it, they would have already been exposed to many of the images the poster makes use of. Nostalgia gave way to the uncanny. One could find oneself engrossed in the poster, a catalogue of AIDS archive images that echoed their experience. In this way, within the exhibition, Cajkovac was making space for himself, the museum, and the viewer to question the role that nostalgia plays in their own experience of the epidemic, including the ways it is represented.

\section{Conclusion}

First and foremost, HIV is a virus that according to the World Health Organization lives in 36.9 million people world wide, and according to amfAR, the Foundation for AIDS Research, is related to the AIDS-related deaths of over 39 million people since we started keeping count. Outside the body the presence of HIV has political, social, spiritual, physical and cultural implications. To make sense of the virus and its ramifications one needs to embrace its assemblage realities, the accumulation of meanings, scientific knowledge, personal experience and everything else. With Treichler again on his mind, Čajkovac reminds us in the exhibition catalogue that AIDS - among all of its definitions - is also an epidemic of meanings.

In Tangled Memories (1997), theorist Marita Sturken writes about how scenes from films about historical moments come to replace memories of those who lived through the actual experiences being represented. The more time passes between the earliest days of AIDS and the present, the harder it will be to have a discussion about HIV rooted in the stories of long-term survivors and witnesses as the primary resource. 'AIDS - Based on a True Story' does not try to stop the movement of time, deny the power of nostalgia, or the flow of media creation. Rather it works to question how we receive information about the epidemic, giving us speed-bumps along the way to consider what we are taking in, and what we want to do with that information.

Media literacy is one tool those involved in the ongoing response to HIV need to keep sharpening. In 'AIDS - Based on a True Story,' Čajkovac helped challenge what we think we know, and gave us the space to consider how narratives around HIV/AIDS are formed and the function they provide in circulation. By questioning knowledge we open up the possibility to learn more, and rid ourselves of unhelpful or outdated information, better enabling a possibility for us to work together to produce narratives for a better future.

\section{Union Theological Seminary, New York}

\footnotetext{
Notes

'AIDS -Based on a True Story', September 5, 2015 - February 21, 2016, Deutsches Hygiene-Museum, Lingnerplatz 1, 01069, Dresden, Germany. Curated by Vladimir Čajkovac.

Tyrone Palmer, 'Under the Rainbow', The New Inquiry, 28 July 2015,

<http://thenewinquiry.com/essays/under-the-rainbow/ > [accessed 1 June 2016]. Pietro Vernazza, Bernard Hirschel, Enos Bernasconi and Markus Flepp, 'HIV-positive individuals not suffering from any other STD and adhering to an effective antiretroviral treatment do not transmit HIV sexually', trans. by Edwin J. Bernard, Bulletin des médecins suisses 89 (5), (30 January 2008) <http://tinyurl.com/cpyt5n> [accessed 21 July 2013].
} 
$5 \quad$ Deutsche Hygiene-Museum Dresden, 'A Forum For Science, Culture and Society, $<$ http://www.dhmd.de/index.php?id=199> [accessed 15 June 2016].

Paula A. Treichler cited in Vladimir Cajkovac, 'AIDS - A Disease as Media Event', in AIDS: Based On A True Story, ed. by Vladimir Cajkovac, trans. by Stephen Grynwasser (Dresden: Verlag des Deutschen Hygiene-Museums, 2015), pp.16-19 (p. 18). Audre Lorde, Uses of the Erotic: The Erotic As Power by Audre Lorde (Trumansburg, NY: Crossing Press, 1984), pp. 53-60 (p. 54).

Klause Vogel, 'Preface', in AIDS: Based On A True Story, ed. by Vladimir Cajkovac, trans. by Stephen Grynwasser (Dresden: Verlag des Deutschen Hygiene-Museums, 2015), p. 3.

Vladimir Cajkovac, 'AIDS - A Disease as Media Event', in AIDS: Based On A True Story, ed. by Vladimir Cajkovac, trans. by Stephen Grynwasser (Dresden: Verlag des Deutschen Hygiene-Museums, 2015), pp.16-19 (p. 17).

Vincent Chevalier and Ian Bradley-Perrin, 'Your Nostalgia is Killing Me,' postervirus.tumblr.com < http://postervirus.tumblr.com/post/67569099579/yournostalgia-is-killing-me-vincent-chevalier $>$ [accessed 15 June 2016].

\section{Works Cited}

Cajkovac, Vladimir, 'AIDS - A Disease as Media Event', in AIDS: Based On A True Story, ed. by Vladimir Cajkovac, trans. by Stephen Grynwasser (Dresden: Verlag des Deutschen Hygiene-Museums, 2015), pp.16-19

Chevalier, Vincent and Ian Bradley-Perrin, 'Your Nostalgia is Killing Me', postervirus.tumblr.com, < http://postervirus.tumblr.com/post/67569099579/your-nostalgia-iskilling-me-vincent-chevalier $>$ [accessed: 15 June 2016]

Deutsche Hygiene-Museum Dresden, 'A Forum For Science, Culture and Society,' < http://www.dhmd.de/index.php?id=199> [accessed: 15 June 2016]

Lorde, Audre, 'Uses of the Erotic: The Erotic As Power', in Sister Outsider: Essays and Speeches by Audre Lorde (Trumansburg, NY: Crossing Press, 1984), pp. 53-60

Palmer, Tyrone, 'Under the Rainbow', The New Inquiry, 28 July 2015, <http://thenewinquiry.com/essays/under-the-rainbow/ > [accessed 1 June 2016]

Vernazza, Pietro, Bernard Hirschel, Enos Bernasconi and Markus Flepp, 'HIVpositive individuals not suffering from any other STD and adhering to an effective antiretroviral treatment do not transmit HIV sexually', trans. by Edwin J. Bernard, Bulletin des médecins suisses 89 (5), (30 January 2008) < http://tinyurl.com/cpyt5n > [accessed: 21 July 2013]

Vogel, Klause, 'Preface', in AIDS: Based On A True Story, ed. by Vladimir Cajkovac, trans. by Stephen Grynwasser (Dresden: Verlag des Deutschen Hygiene-Museums, 2015), p. 3 